\title{
Studi Komparatif Daya Tahan Kardiovaskular (VO2MAX) Peserta Unit Kegiatan Mahasiswa Taekwondo Putra yang Perokok dan Bukan Perokok di Universitas Negeri Malang
}

\author{
Dieo Surya Permana Putra, Siti Nurrochmah*, Fahrial Amiq \\ Universitas Negeri Malang, Jl. Semarang No. 5 Malang, Jawa Timur, Indonesia \\ *Penulis korespondensi, Surel: siti.nurrochmah.fik@um.ac.id
}

Paper received: 4-1-2022; revised: 21-1-2022; accepted: 28-1-2022

\begin{abstract}
The objective of this study was to determine the differences in the level of cardiovascular endurance of smokers and non-smokers of Taekwondo UKM participants at the State University of Malang. The design used is in the form of a quantitative descriptive survey. The subjects were 32 participants of taekwondo UKM at the State University of Malang. The instrument used are multi-stage running test. The data obtained were analyzed for normality test using the Kolmogorov-Smirnov technique and the homogeneity test of variance using the Hartley Fmax technique. And the analysis test is different in the form of the free sample $t$ test. The results of the analysis of sig. D. $=0.0954,>=0.05$ and the results of the data on the non-smoking variable coefficient obtained sig. D. $=0.1941,>=0.05$. F $\max$ analysis results obtained $F_{\text {hit }}=1.03<F_{\text {tab }} 2.37$ (data is normally distributed and the population variance is homogeneous). And the t-test form of hypothesis testing obtained $t_{\text {hit }}$ results. $3.29017>$ $t_{\text {tab }}$ 0.05. The conclusion of this study is that there are differences in cardiovascular endurance among smokers and non-smokers of taekwondo UKM participants at the State University of Malang. smokers have poor cardiovascular endurance compared to non-smokers. Suggestions for UKM participants who smoke to stop smoking habits. Meanwhile, non-smokers UKM participants are expected not to try to consume cigarettes.
\end{abstract}

Keywords: $\mathrm{VO}_{2} \mathrm{Max}$, taekwondo, smoking, and non-smoking

\begin{abstract}
Abstrak
Penelitian ini bertujuan untuk mengetahui perbedaan daya tahan kardiovaskuler peserta UKM taekwondo perokok dan bukan perokok di Universitas Negeri Malang. Rancangan yang digunakan berupa survei bentuk deskriptif kuantitatif. Subjek berjumlah 32 peserta UKM taekwondo di Universitas Negeri Malang. Instrumen yang digunakan berupa tes lari multitahap. Data yang diperoleh dianalisis normalitasnya dengan metode Kolmogorov-Smirnov dan homogenitas varians diperiksa dengan metode Hartley Fmax. Pengujian analitik juga merupakan bentuk lain dari uji-t sampel gratis. Hasil analisis sig. D. $=0,0954,>\alpha=0,05$ dan hasil data pada variabel bukan perokok koefisien diperoleh sig. $D_{.}=0,1941,>\alpha=0,05$. hasil analisis $F_{\text {maks }}$ diperoleh $F_{\text {hit }}=1,03<F_{\text {tab }} 2,37$ (data berdistribusi normal dan varian populasi homogen). Dan uji hipotesis bentuk uji t diperoleh hasil thit. 3,29017 > tab $\alpha$ 0,05. Kesimpulan dari penelitian ini adanya perbedaan daya tahan kardiovaskuler antara perokok dan bukan perokok peserta UKM Taekwondo Universitas Negeri Malang. Perokok memiliki daya tahan kardiovaskular yang lebih rendah dibandingkan non-perokok. Saran bagi peserta UKM merokok untuk mengurangi dan/atau berhenti merokok. Di sisi lain, peserta UKM nonmerokok tidak boleh mencoba untuk merokok.
\end{abstract}

Kata kunci: $\mathrm{VO}_{2} \mathrm{Max}$, taekwondo, perokok, dan bukan perokok.

\section{Pendahuluan}

Olahraga merupakan suatu bentuk aktivitas fisik yang dinikmati oleh banyak kalangan, mulai dari anak-anak hingga remaja, dewasa, laki-laki dan perempuan, yang tidak hanya mencakup aspek fisik tetapi juga aspek mental. Olahraga juga sebagian dari kegaiatan aktivitas 
sehari-hari manusia yang dengan tujuan kebugaran jiwa dan raga (Haryesa \& Hariyoko, 2021). Untuk memperoleh kebugaran dan kesehatan, olahraga juga dapat dilakukan dimanapun, kapanpun dan oleh siapapun. Susandi \& Wikananda (2018) "Olahraga merupakan kegiatan hidup manusia yang tidak hanya meliputi aspek fisik tetapi juga aspek mental, sosial bahkan ekonomi".

Salah satu hal yang menunjang keberhasilan olahraga adalah kondisi fisik atlet. Aktivitas fisik seperti berolahraga dapat meningkatkan daya tahan kardiorespirasi yang baik (Raya et al., 2019). Kondisi fisik sangat berpengaruh terhadap kinerja seseorang baik dalam situasi latihan maupun pertandingan untuk tampil dalam rangka mencapai kemenangan suatu pertandingan. Hardiansyah (2018), berpendapat bahwa "penyebab kesalahan gerakan salah satunya ditentukan oleh keadaan kemampuan kondisi fisik seperti unsur kekuatan kecepatan, daya tahan dan kemampuan koordinasi. Berarti daya tahan termasuk sebagai salah satu faktor penyebab kesalahan gerakan yang ditampilkan. Dalam jenis olahraga unjuk kerjanya seperti jenis olahraga yang lainya termasuk olahraga taekwondo tergantung pada keadaan tingkat kondisi fisik. Kebugaran adalah kemampuan seseorang untuk melakukan kerja fisik dengan keterampilan langkah demi langkah. Kebugaran merupakan faktor yang sangat penting, sehingga penting untuk meningkatkan komponen kebugaran melalui latihan yang sistematis, terencana dan berkesinambungan Hampir semua cabang olahraga membutuhkan komponenkomponen kemampuan kondisi fisik, termasuk olahraga taekwondo. Kemampuan kondisi fisik mempunyai peranan penting untuk menunjang gerak bermain yang dilakukan selama $4 \times 10$ menit, dan menunjang atau mendukung kinerja keterampilan teknik dasar. Adapun beberapa komponen yang harus dimiliki oleh olahragawan antara lain: (a) kekuatan otot komponen kondisi fisik dasar wajib harus ada, (b) kecepatan, (c) kelentukan, (d) kelincahan, (e) daya ledak otot, (f) ketepatan, (g)kecepatan reaksi, (h) daya tahan tubuh, (i) dan koordinasi gerak (Harsono, 2017). Bompa \& Buzzichelli (2015) berpendapat jika seseorang ingin sukses atau berhasil dalam kinerja olahraga, maka atlet seharusnya memiliki, komponen biomotor berupa komponen-komponen kondisi fisik seperti kekuatan otot, kecepatan, daya ledak otot, kelenturan, kelincahan, dan daya tahan otot.

Kondisi fisik sangat berpengaruh pada nilai volume oksigen maksimal $\left(\mathrm{VO}_{2} \mathrm{Max}\right)$ seorang atlet. Menurut Turege et al., (2019), Faktor yang mempengaruhi kebugaran adalah usia, jenis kelamin, genetik dan aktivitas fisik. Saat ini, merokok telah menjadi kebiasaan bagi orang dewasa dan remaja, dan merokok juga telah menjadi gaya hidup bagi para atlet, meskipun mereka sadar akan efek dan efek berbahaya dari merokok. Kasubdit Penyakit Paru Kronik dan Gangguan Imunologi Kementerian Kesehatan dr. Theresia Sandra Diah Ratih mengatakan, lebih dari 60 juta orang saat ini merokok di Indonesia. Dari jumlah tersebut, mayoritas perokok aktif berasal dari anak-anak berusia antara 10 dan 18 tahun. Jumlah anak dan remaja yang merokok meningkat sebesar 8,8\% pada tahun 2016 dan meningkat setiap tahunnya. Menurut Menurut Alamsyah (2017), Perilaku merokok adalah perilaku yang melibatkan proses pembakaran tembakau, diikuti dengan merokok dengan tembakau atau pipa. Perilaku merokok terlihat tidak hanya pada orang dewasa tetapi juga pada masa remaja. Subjek merasakan lebih banyak kegembiraan, kepuasan, dan ketenangan selama atau setelah merokok. Perokok juga dapat melanjutkan merokok ketika mereka stres dan meningkatkan intensitas merokok. Semakin tinggi tingkat stres maka semakin tinggi pula perilaku merokok remaja dan begitu pula sebaliknya. (Bawuna et al., 2017). 
Sejumlah besar energi dihasilkan oleh sistem kardiovaskular yang membutuhkan oksigen dan semakin tinggi kapasitas oksigen maksimum atlet, semakin besar daya tahan kardiovaskular atlet sebelum setiap pertandingan. Oleh karena itu, tingkat daya tahan kardiovaskuler seorang atlet tergantung pada kapasitas oksigen yang tinggi atau VO2max yang tinggi. Menurut Hartanto \& Hariyoko (2020), "daya tahan kardiovaskular atau daya tahan yang memenuhi kebutuhan fisik dalam melakukan kegiatan sehari-hari. Menurut Atradinal (2018) "daya tahan adalah kemampuan untuk bekerja dalam waktu yang lama". Sedangkan Menurut Rahmad (2016), "Daya tahan kardiovaskular adalah kemampuan paru-paru, jantung, dan pembuluh darah untuk memasok sel dengan sejumlah oksigen dan nutrisi untuk memenuhi kebutuhan jangka panjang mereka". Dalam kegiatan olahraga, tingkat daya tahan sangat menunjang dan merupakan modal yang sangat penting untuk dapat mencapai prestasi setinggi-tingginya dan merupakan hal yang paling dibutuhkan untuk memenangkan suatu kejuaraan atau pertandingan. Daya tahan atlet juga merupakan hal yang sangat berpengaruh untuk berkonsentrasi dan fokus untuk memenangkan suatu pertandingan.

Rokok Tembakau mengandung 4000 bahan kimia, 200 di antaranya bersifat karsinogenik (dapat penyebab kanker), dan zat beracun ini adalah asap primer, yaitu asap tembakau dan asap rokok, yang dihirup langsung ke paru-paru perokok. dihasilkan oleh asap tembakau selama pembakaran. Puntung rokok seperti karbon monoksida, benzopyrene, dan amoniak. (Siregar \& Rambe, 2020). Kendala yang sering terjadi pada atlet taekwondo yang berstatus sebagai mahasiswa adalah mempunyai kebiasaan merokok. Mahasiswa yang mempunyai kebiasan merokok kemungkinan akan terdampak pada kesegaran jasmani, minimal sebagai faktor resiko yang terjadinya berbagai jenis penyakit. Menurut Nahak \& Kora (2017), "tidak mudah Mengontrol, mengurangi atau bahkan menghilangkan keinginan untuk merokok memang tidak mudah". Kebiasaan merokok remaja dipengaruhi oleh beberapa faktor, terutama pada tahap perkembangan anak yang sedang mencari individualitas dan selalu ingin mencoba hal-hal baru di lingkungannya. (Munir, 2019). Gaya hidup merokok ini merupakan masalah kesehatan dan setidaknya menjadi faktor risiko berbagai penyakit. Kelemahan perokok ditandai dengan ketidaknyamanan yang cepat dan sirkulasi yang buruk selama beberapa minggu. Ini berarti terlalu banyak zat beracun yang masuk ke sistem pernapasan. Atlet taekwondo dengan aktivitas fisik yang tinggi mengalami gangguan system kerja jantung paru-paru dan sangat merugikan dirinya sendiri.

Bagi semua peserta unit kegiatan mahasiswa taekwondo putra, memiliki kondisi yang prima akan sangat menguntungkan bagi diri sendiri dan memudahkan untuk melakukan teknik dan strategi yang diinginkan dalam suatu pertandingan begitu sebaliknya bagi anggota unit kegiatan mahasiswa putra taekwondo yang merokok akan sangat merugikan karena asap rokok masuk ke dalam bagian tubuh dan akan mempengaruhi sistem pernafasan yang mengakibatkan tidak lancarnya saluran metabolisme dalam tubuh. Menurut Putra (2020), "Merokok adalah peningkatan aktivitas otot di bawah kerongkongan, yang secara perlahan melemahkan otot-otot di sekitar saluran pernapasan bagian bawah dan semakin mengganggu pencernaan".

Berdasarkan hasil observasi dan hasil wawancara yang dilakukan peneliti pada tanggal 27 Maret 2020 pada jam 15.30 WIB di unit kegiatan mahasiswa Universitas Negeri Malang mendapat hasil berupa 32 siswa yang mengikuti unit kegiatan mahasiswa Taekwondo, 17 peserta unit kegiatan mahasiswa taekwondo merupakan perokok dan 15-unit kegiatan mahasiswa taekwondo bukan perokok. 
Daya tahan kardiovaskular $\left(\mathrm{VO}_{2} \mathrm{Max}\right)$ sangat dibutuhkan dalam berbagai aktivitas olahraga, unjuk kerja dilapangan sangat tergantung salah satunya pada komponen kondisi fisik daya tahan pada Unit kegiatan mahasiswa Universitas Negeri Malang khususnya cabang olahraga taekwondo selama ini menjadi anggota unit kegiatan mahasiswa. Latihan dan teknik latihan ditujukan untuk meningkatkan komponen kebugaran seperti kecepatan, kelenturan, kelincahan dan daya tahan. Latihan untuk melakukan kegiatan tersebut dibutuhkan komponen daya tahan untuk melakukan kegiatan latihan individu mampu melakukan latihan dalam hitungan yang lama. Peserta unit kegiatan mahasiswa olahraga taekwondo di Universitas Negeri Malang terdapat peserta kelompok putra dan putri. Khusus pada kelompok putra terdapat karakteristik peserta perokok dan bukan perokok. Merokok berhubungan dengan komponen daya tahan. Untuk mengetahui dampak merokok dengan komponen daya tahan tersebut dilakukan suatu kajian. Masalah merokok dan daya tahan terhadap aktivitas tes olahraga taekwondo memungkinkan untuk dikaji. Peneliti tertarik untuk mengambil atau mengkaji masalah tersebut melalui penelitian. Oleh karena itu, dilakukan tindakan pengkajian melalui penelitian dengan judul "Studi Komperatif Daya Tahan Kardiovaskular $\left(\mathrm{VO}_{2} \mathrm{Max}\right)$ Peserta Unit Kegiatan Mahasiswa Taekwondo Putra Perokok dan Bukan Perokok di Universitas Negeri Malang Kota Malang”.

Taekwondo adalah beladiri yang asalnya dari Korea yang juga sebagai olahraga nasional Korea. Menurut Kamal et al., (2019), "Dalam bahasa Korea, kanji hanja berarti menendang atau menghancurkan dengan kaki, kwon berarti tinju, dan do berarti jalanan atau seni". Taekwondo pada dasarnya memiliki naluri untuk selalu melindungi diri sendiri dan hidup Anda. Taekwondo juga membentuk sikap mental yang kuat dan akhlak yang baik bagi mereka yang benar-benar mempelajarinya. Menurut Sabatini et al., (2019), "taekwondo olahraga bela diri yang merupakan olahraga nasional Korea dan dipertandingkan di Olimpiade". Taekwondo tidak hanya menekankan aspek seperti keterampilan bertarung, tetapi juga aspek yang mengajarkan disiplin spiritual. Dalam ajang turnamen dan final taekwondo, pemain bermain melawan satu sama lain beberapa kali, tidak hanya sekali. Oleh karena itu, atlet harus memiliki kondisi fisik yang cukup baik dan tenaga yang cukup baik untuk melanjutkan pertandingan selanjutnya agar dapat mencapai final.

Beberapa penelitian terdahulu seperti Utomo (2012) mengatakan "Perbandingan Daya Tahan Kardiorespirasi Antara Siswa Perokok dan Siswa Tidak Perokok Aktif Berolahraga menunjukkan adanya perbedaan daya tahan kardiorespirasi yang signifikan antara siswa perokok aktif berolahraga dan bukan perokok aktif berolahraga terdapat perbedaan yang signifikan, dimana siswa perokok aktif berolaharaga digolongkan baik dari pada yang perokok.

Sedangkan penelitian yang dilakukan oleh Kurniadi et al., (2019), mengatakan "terdapat perbedaan daya tahan kardiorespirasi siswa ekstrakurikuler yang memiliki kebiasaan merokok dengan siswa yang tidak merokok. Tujuan penelitian untuk mengetahui ada dan tidaknya perbedaan secara signifikan daya tahan kardiovaskular $\left(\mathrm{VO}_{2} \mathrm{Max}\right)$ antara peserta putra perokok dan bukan perokok pada unit kegiatan mahasiswa Taekwondo Universitas Negeri Malang.

\section{Metode}

Rancangan penelitian ini menggunakan rancangan survei bentuk deskriptif kuantitatif dan metode pendekatan yang digunakan berupa metode observasi. Penelitian yang dilakukan 
berupa penelitian kasual komparatif. Populasi dalam penelitian ini adalah peserta unit kegiatan mahasiswa cabor taekwondo berjumlah 36 orang. Dan teknik pengambilan sampel menggunakan teknik observasi dengan penyebaran instrumen perokok dan bukan perokok. Sehingga jumlah sampel 32 orang. Instrumen yang akan digunakan merupakan instrumen tes yaitu tes lari multitahap. Data yang diperoleh dan dikumpulkan dalam penelitian dengan melakukan observasi atau pengamatan, wawancara dengan pelatih serta hasil dari penyebaran angket kepada peserta unit kegiatan mahasiswa taekwondo. Sedangkan sumber data dalam penelitian ini yaitu peserta unit kegiatan mahasiswa taekwondo dengan jumlah 32 mahasiswa dengan kelompok 17 perokok dan 15 bukan perokok. Analisis data menggunakan statistika inferensial Sampel uji t bebas. Sebelumnya dilakukan analisis data menggunakan pre-test sebagai berikut: (a) Pengecekan normalitas data menggunakan metode Kolmogorov-Smirnov. Jika $=0,05$ maka nilai yang dinyatakan berdistribusi normal, dan sebaliknya jika nilai signifikan $>=0,05$ maka nilai yang dinyatakan berdistribusi normal. Kemudian (b) metode Hartley Fmax dan uji T (Kadir, 2016) digunakan untuk menguji keseragaman varians dalam kelompok. Dalam pengujian ini, analisis data sebagian dilakukan secara manual. Perangkat lunak statistik SPSS25 untuk Windows 10.

\section{Hasil dan Pembahasan}

\subsection{Hasil}

Berikut hasil penelitian data dianalisis menggunakan statistika deskriptif hasil analisis tes daya tahan kardiovaskular ( $\mathrm{VO}_{2} \mathrm{Max}$ ) peserta unit kegiatan mahasiswa taekwondo yang perokok dan bukan perokok, yaitu.

Tabel 1. Perbedaan Daya Tahan Kardiovaskular $\left(\mathrm{VO}_{2} \mathrm{Max}\right)$ Peserta Unit Kegiatan Mahasiswa Taekwondo yang Perokok dan Bukan Perokok

\begin{tabular}{|c|c|c|c|c|c|c|c|}
\hline Variabel & $\begin{array}{l}\text { Kelompo } \\
\mathrm{k}\end{array}$ & $\begin{array}{l}\text { Sko } \\
\text { r } \\
\text { Min. }\end{array}$ & $\begin{array}{l}\text { Skor } \\
\text { Maks }\end{array}$ & $\begin{array}{l}\text { Modus(f } \\
\text { ) }\end{array}$ & Mean & SD. S & $\begin{array}{l}\text { Varian. } \\
\text { S }\end{array}$ \\
\hline \multirow{2}{*}{$\begin{array}{l}\text { Daya tahan } \\
\text { kardiovaskula } \\
\left.\text { r (VO2 } 2_{\max }\right)\end{array}$} & Perokok & 35,8 & 53,1 & $\begin{array}{l}47,4(f= \\
3)\end{array}$ & $\begin{array}{l}45,167 \\
6\end{array}$ & $\begin{array}{l}4,873 \\
1\end{array}$ & $\begin{array}{l}23,747 \\
7\end{array}$ \\
\hline & $\begin{array}{l}\text { Bukan } \\
\text { Perokok }\end{array}$ & 39,2 & 55,4 & $\begin{array}{l}53,1(f= \\
2)\end{array}$ & $\begin{array}{l}50,773 \\
3\end{array}$ & $\begin{array}{l}4,735 \\
8\end{array}$ & $\begin{array}{l}22,427 \\
8\end{array}$ \\
\hline
\end{tabular}

Berdasarkan paparan analisis deskriptif data hasil tes lari multitahap yang disajikan pada tabel 1 tersebut di atas, perhitungan hasil tes daya tahan kardiovaskular $\left(\mathrm{VO}_{2} \mathrm{Max}\right)$ untuk peserta unit kegiatan mahasiswa taekwondo yang perokok memiliki jumlah modus yaitu frekuensi yang paling banyak adalah pada skor 47,4 detik dan frekuensi $=3$ pada kelompok perokok, untuk hasil mean yaitu 45,1676. Pada varian sampel memiliki hasil yaitu 23,7477. Sedangkan pada kelompok bukan perokok memiliki jumlah modus yaitu skor yang paling banyak muncul adalah 53,1 detik berjumlah $2(\mathrm{f}=2$ ) pada kelompok bukan perokok, untuk hasil mean yaitu 50,7733 dan hasil standar deviasi sampel perokok 4,7358. Pada varian sampel memiliki hasil yaitu 22,4278. Hasil analisis deskriptif tersebut diketahui bahwa rata-rata hasil tes daya tahan kardiovaskuler kelompok bukan perokok rata-rata hitung lebih besar. Berdasarkan hasil perhitungan menggunakan teknik Kolmogorov-Smirnov menjelaskan bahwa masing-masing data daya tahan kardiovaskular $\left(\mathrm{VO}_{2} \mathrm{Max}\right)$ menunjukkan hasil analisis data pada variable perokok koefisien diperoleh $D_{\text {hit. }}=0,0954341$, sedangkan $D_{\text {tab. }} \alpha=0,05=0,318$ 
dan hasil data pada variabel bukan perokok koefisien diperoleh $D_{\text {hit. }}=0,1941631$ sedangkan $D_{\text {tab. }} \alpha=0,05=0,338$. Oleh karena pada kedua kelompok hasil analisis diperoleh $D_{\text {hit. }}<D_{\text {tab. }} \alpha$ 0.05 (lebih kecil Dalam hal 0,05), ini berarti hipotesis kerja ditolak dan hipotesis nol diterima. Artinya, data untuk kedua kelompok menunjukkan distribusi normal. Berdasarkan hasil perhitungan menggunakan teknik Hartley $F_{\text {maks }}$ diperoleh $F_{\text {hit }}=1,03$ dan $F_{\text {tab. }}$ 2,37. Oleh karena data hasil tes daya tahan diperoleh $\mathrm{F}_{\text {hit. }}<\mathrm{F}_{\text {tab. }} \alpha 0,05$ (lebih kecil dari 0,05), berarti hipotesis kerja ditolak dan hipotesis nihil diterima. Dan Berdasarkan hasil analisis uji t sampel bebas data menunjukkan bahwa koefisien $t_{\text {hit. }} 3,29017$ dan $t_{\text {tab }} \alpha 0,05 \mathrm{db} .30=1,697$. Oleh karena data hasil tes daya tahan diperoleh $t_{\text {hit. }}>\mathrm{t}_{\mathrm{tab}} . \alpha 0,05$, berarti terdapat perbedaan rata-rata daya tahan kardiovaskular $\left(\mathrm{VO}_{2} \mathrm{Max}\right)$ antara kelompok perokok dan bukan perokok

\subsection{Pembahasan}

Penelitian yang ini dilakukan dengan bertujuan untuk mengetahui keadaan kondisi fisik unsur daya tahan kardiovaskular tubuh mengingat komponen tersebut mempunyai peranan penting dalam aktivitas olahraga termasuk olahraga prestasi. Kompetensi fisik dalam olahraga merupakan komponen performa atletik atau kondisi fisik yang dibutuhkan oleh semua atlet tergantung pada cabang olahraganya. Tubuh adalah dasar untuk hasil, karena atlet yang sehat secara fisik dapat sepenuhnya mengembangkan keterampilan, taktik, dan mentalitas mereka. (Nurrochmah, 2016). Kondisi fisik dalam fungsional dari peralatan fisik seseorang untuk memenuhi persyaratan dan spesifikasi yang optimal dari olahraga tertentu. (Edwarsyah et al., 2019). Berarti kondisi fisik sangat dibutuhkan dalam aktivitas olahraga. Bompa \& Buzzichelli (2015) mengatakan bahwa kebugaran merupakan salah satu syarat yang harus dimiliki oleh setiap atlet dan olahragawa juga merupakan modal dasar untuk meningkatkan potensi seorang atlet. Kapasitas fisik merupakan faktor penting dan menjadi dasar bagi perkembangan teknis, taktis/strategis dan intelektual atlet (Sidik, 2019).

Dalam kajian ini komponen kondisi fisik yang diteliti adalah komponen daya tahan kardiovascular. Menurut Kharisma \& Mubarok (2020), mengungkapkan bahwa daya tahan aerobik atau daya tahan jantung dan paru adalah kemampuan jantung, paru-paru, dan pembuluh darah untuk berfungsi secara optimal selama aktivitas sehari-hari dalam waktu jangka panjang tanpa merasa lelah.

Daya tahan merupakan satu komponen kondisi fisik yang sangat dibutuhkan dalam beberapa cabang olahraga. Daya tahan juga merupakan salah satu faktor yang penting menentukan unjuk kerja olahragawan di lapangan. Hal ini didukung dengan pendapat (Bompa \& Buzzichelli, 2015). (Clark et al., 2015) yang mengatakan bahwa faktor-faktor kondisi fisik yang menentukan keberhasilan/ kesuksesan penampilan dalam pencapaian prestasi olahraga adalah unsur kekuatan otot, kecepatan gerak, kelentukan, dan daya tahan tubuh utamanya daya tahan kardiovaskuler. Komponen tersebut sebagai komponen yang utama, sehingga penting dikembangkan dan dilatih. Diantara beberapa komponen kondisi fisik tubuh tersebut utamanya adalah komponen daya tahan kardiovaskuler. Berarti komponen daya tahan merupakan salah satu komponen kondisi fisik yang peranan penting dalam unjuk kerja di lapangan baik latihan maupun pertandingan/perlombaan. Adanya perbedaan daya tahan perokok lebih rendah dibandingkan dengan bukan perokok, hal ini disebabkan pada rokok ada kandungan zat nicotin yang terdapat di dalam tembako. Zat nikotin menstimulasi medulla glandulla suprarenalis, sehingga lebih banyak adrenalin dikeluarkan. Adrenalin menimbulkan vasodilatasi pada coronarino dan arteriae di dalam otot. Adrenalin menimbulkan kenaikan 
frekuensi detak jantung sehingga menimbulkan kontraksi otot jantung bertambah kuat (Plowmann \& Smith, 2017). Dengan demikian dapat dikemukakan bahwa seseorang yang memiliki kebiasaan merokok terdampak pada komponen kondisi fisik yang kurang baik khususnya komponen daya tahan kardiovaskular, sehingga hal ini dapat mengganggu unjuk kerja fisik padaa waktu latihan maupun unjuk kerja pada waktu pertandingan atau perlombaan. Orang yang tidak merokok lebih bugar dan kemampuan fisik yang dimiliki lebih baik dibandingkan dengan mereka yang merokok dan kebugaran dan kemampuan yang rendah dimiliki oleh mereka yang merokok (Hariadi et al., 2018). Berdasarkan hasil penelitian dan paparan kontroversial, dapat dikatakan di seluruh dunia bahwa ada perbedaan yang signifikan dalam resistensi kardiovaskular antara perokok dan bukan perokok, yang didukung oleh beberapa hipotesis.

\section{Simpulan}

Berdasarkan tujuan penelitian untuk mengetahui ada tidaknya perbedaan yang signifikan daya tahan kardiovaskular $\left(\mathrm{VO}_{2} \mathrm{Max}\right)$ antara peserta putra perokok dan bukan perokok pada unit kegiatan mahasiswa Taekwondo Universitas Negeri Malang. Hasil dari analisis dapat disimpulkan bahwa adanya perbedaan signifikan daya tahan kardiovaskuler $\left(\mathrm{VO}_{2} \mathrm{Max}\right)$ peserta unit kegiatan mahasiswa taekwondo yang perokok dan bukan perokok dimana peserta yang merokok memiliki daya tahan kardiovaskular yang kurang baik dibandingkan dengan yang bukan perokok.

\section{Daftar Rujukan}

Alamsyah, A. (2017). Determinan Perilaku Merokok Pada Remaja. Jurnal Endurance, 2(1), 25. https://doi.org/10.22216/jen.v2i1.1372

Atradinal, A. (2018). Pengaruh Model Latihan Fartlek Terhadap Daya Tahan Aerobik Atlet Sekolah Sepakbola Psts Tabing. Sporta Saintika, 3(1), 432. https://doi.org/10.24036/sporta.v3i1.63

Bawuna, N. H., Rottie, J., \& Onibula, F. (2017). Hubungan Antara Tingkat Stres Dengan Perilaku Merokok Pada Mahasiswa Fakultas Teknik Universitas Sam Ratulangi. Jurnal Keperawatan UNSRAT, 5(2), 107578.

Bompa, T., \& Buzzichelli, C. A. (2015). Periodization Training for Sports. Human Kinetics.

Clark, M. ., Lucett, S. ., \& Sutton, B. . (2015). Sports Performance Training. Jones \& Bartlett.

Edwarsyah, Hardiansyah, S., \& Syampurma, H. (2019). Pengaruh Metode Pelatihan Circuit Training YTerhadap Kondisi Fisik ATlet Pencak Silat Unit Kegiatan Olahraga Universitas Negeri Padang. Journal of Chemical Information and Modeling, 53(9), 1689-1699.

Hardiansyah, S. (2018). Kondisi Fisik Adalah Salah Satu Prasarat Yang Sangat Diperlukan Dalam Setiap Usaha Peningkatan Prestasi Seorang Atlet, Bahkan Dapat Dikatakan Dasar Landasan Titik Tolak Suatu Awalan Olahraga Prestasi. Jurnal Menssana, 3(1), 117-123.

Hariadi, R. A., Widjanarko, B., \& Jati, S. P. (2018). Studi Analisis Tahap Pembentuk Efikasi Diri Dalam Upaya Berhenti Merokok Pada Klien Klinik Berhenti Merokok di Balkesmas Wilayah Semarang. Al-Sihah: The Public Health Science Journal, 10(2), 138-147. https://doi.org/10.24252/as.v10i2.6052

Harsono, S. (2017). Kepelatihan Olahraga (A. Kamsyah (ed.)). PT Remaja Rosdakarya.

Hartanto, S., \& Hariyoko. (2020). Kontribusi Indeks Massa Tubuh dan Daya Tahan Kardiovaskular dengan Keterampilan Dasar Futsal Sekolah Menengah Atas. Sport Science and Health, 2(5), 279-284.

Haryesa, M. A., \& Hariyoko, H. (2021). Survei Daya Tahan Kardiovaskular (VO2max) dan Kelincahan Peserta Ekstrakurikuler Futsal di Sekolah Menengah Pertama (SMP). Sport Science and Health, 3(2), 78-84. https://doi.org/10.17977/um062v3i22021p78-84

Kamal, M. J., Nuryanto, N., \& Prabowo, N. A. (2019). Sistem Filterisasi Pada Pendaftaran Online Pertandingan Taekwondo Cup Di Kota Magelang. Jurnal Komtika, 2(2), 109-114. https://doi.org/10.31603/komtika.v2i2.2597

Kharisma, Y., \& Mubarok, M. Z. (2020). Analisis Tingkat Daya Tahan Aerobik Pada Atlet Futsal Putri AFKAB Indramayu. Physical Activity Journal, 1(2), 125. https://doi.org/10.20884/1.paju.2020.1.2.2349 
Kurniadi, D. A. E., Wahyudi, U., \& Heynoek, F. P. (2019). Hubungan Kebiasaan Merokok terhadap Tingkat Kesegaran Jasmani Peserta Ekstrakurikuler Futsal Putra. Sport Science and Health, 1(2), 126-131.

Munir, M. (2019). Gambaran Perilaku Merokok Pada Remaja Laki-Laki. Jurnal Kesehatan, 12(2), 112. https://doi.org/10.24252/kesehatan.v12i2.10553

Nahak, johanes F., \& Kora, F. T. (2017). Hubungan Merokok Dengan Terjadinya Insomnia Pada Remaja Karang Taruna. Jurnal Kesehatan Samodra Ilmu, 8(9), 1-58.

Nurrochmah, S. (2016). Tes dan Pengukran dalam Pendidikan Jasmani dan Keolahragaan. UM Press.

Plowmann, S. A., \& Smith, D. L. (2017). Exercise Physiology for Health, Fitness and Performance. Wolters Kluwer.

Putra, I. G. N. S. A. K. (2020). Kebijakan Kawasan Tanpa Rokok Terhadap Pengguna Vape (Rokok Elektrik) Di Kabupaten Badung. Jurnal Surya Kencana Satu : Dinamika Masalah Hukum Dan Keadilan, 11(1), 1. https://doi.org/10.32493/jdmhkdmhk.v11i1.5613

Rahmad, H. (2016). Pengaruh Penerapan Daya Tahan Kardivaskuler (Vo Max) Dalam Permaian Sepakbola Ps Bina Utama. Curricula, 2(2), 1-10. https://doi.org/10.22216/jcc.v2i2.1009

Raya, R. I., Yunus, M., \& Adi, S. (2019). Hubungan Intensitas Aktivitas Fisik dan Masa Kerja dengan Prevalensi dan Tingkatan Low Back Pain pada Pekerja Kuli Angkut Pasir. Sport Science and Health, 1(2), 102-109.

Sabatini, N. K. G., Nugraha, M. H. S., \& Dewi, A. A. N. T. N. (2019). Faktor-Faktor Yang Mempengaruhi Kecepatan, Kekuatan, Dan Daya Ledak Terhadap Tendangan Pada Atlet Taekwondo. Jurnal Pendidikan Olahraga, 8(2), 85-95. https://doi.org/10.31571/jpo.v8i2.1120

Sidik, D. Z., Pesurnay, P. L., \& Afari, L. (2019). Pelatihan Kondisi Fisik (Nita (ed.)).

Siregar, R. J., \& Rambe, N. Y. (2020). Penyuluhan tentang Bahaya Merokok pada Pria di Desa Sorimaon Kec. Batang Angkola Muaratais Kab. Tapanuli Selatan Tahun 2020. Jurnal Pengabdian Masyarakat Aufa (JPMA), 2(3), 59-66.

Susandi, D., \& Wikananda, R. (2018). nalisis Beban Pada Olahraga Panahan Dengan Menggunakan Metode Fisiologi. Prosiding Industrial Research Workshop and National Seminar, 9, 432-437.

Turege, J. N., Kinasih, A., \& Kurniasari, M. D. (2019). Hubungan Antara Aktivitas Fisik Dengan Obesitas Di Puskesmas Tegalrejo, Kota Salatiga. Jurnal Ilmu Keperawatan Dan Kebidanan, 10(1), 256. https://doi.org/10.26751/jikk.v10i1.530

Utomo, G. et al. (2012). Journal of Sport Sciences and Fitness - PDF Download Gratis.pdf. Journal of Sport Scinces and Fitness, 5(2), 6-10. 